\title{
The defendant's guilt beyond a reasonable doubt in the Italian criminal justice system
}

\author{
A culpabilidade do réu além de qualquer dúvida \\ razoável no sistema de justiça penal italiano
}

\section{Francesco Callari ${ }^{1}$}

\author{
University of Pisa, Italy \\ francesco.callari@jus.unipi.it \\ https://orcid.org/0000-0003-1815-0149
}

\begin{abstract}
AвSTRACT: The criminal law standard of Beyond A Reasonable Doubt (BARD) constitutes an evidentiary and judicial rule, formulated and applied for centuries in common law jurisdictions, which was expressly stated in the Italian Code of Criminal Procedure only about fifteen years ago. Unfortunately, the concept of reasonable doubt is inherently complex and does not easily lend itself to definition or refinement. In this regard, the Author examines especially the various positions and elaborations developed by legal literature and case-law in Italy, proposing a specific interpretation of the BARD rule that enhances and completes the particular procedural connotations of the adversarial system adopted in the Italian criminal justice.
\end{abstract}

Keywords: reasonable doubt; criminal procedure; presumption of innocence; burden of proof; standard of proof; judicial reasoning method; fair trial.

Resumo: O standard penal do Beyond A Reasonable Doubt (BARD) constitui uma regra de prova e de juízo, formulada e aplicada durante séculos em jurisdições de common law, que foi expressamente introduzida no Código de Processo Penal italiano apenas cerca de quinze anos atrás. Infelizmente, o conceito de

1 PhD in Criminal Procedure, University of Palermo (Italy). Professor of Criminal Procedure, Department of Law, Pisa University (Italy). Teaching Fellow at the RWTH Aachen University (Germany). Expert Judge at the Surveillance Tribunal of Palermo. 
dúvida razoável é inerentemente complexo e não se presta facilmente a uma definição ou a uma melhor delimitação. Diante disso, o autor examina sobretudo as diferentes posições e elaborações desenvolvidas pela doutrina e pela jurisprudência na Itália, oferecendo uma interpretação específica da regra BARD que valoriza e completa as conotações processuais particulares do sistema acusatório adotado na justiça penal italiana.

Palavras-chave: dúvida razoável; processo penal; presunção de inocência; ônus da prova; standard de prova; método de raciocínio judicial; justo processo.

TABle of Contents: 1 . Establishing Criminal Liability Beyond a Reasonable Doubt: Introduction. - 2. The Italian Codification of a Common Law Legal Formula. - 3. "Beyond any Reasonable Doubt" as Evidentiary and Judicial Rule in the Italian Criminal Trial. 4. Conclusion.

\section{Establishing Criminal liability Beyond a Reasonable Doubt: INTRODUCTION.}

The judgment criterion of the "Beyond A Reasonable Doubt" (BARD) rule has a direct impact on the forceful reasons protecting both personal freedom and innocence, which for centuries have been a core subject of reflection on the establishment of the criminal liability in Western legal culture, and in particular in Anglo-American law tradition ${ }^{2}$. However, it is to be noted that currently in Italy there is a renewed

2 For a thorough historical reconstruction of the BARD, see LANGBEIN, John H. The Origins of Adversary Criminal Trial. Oxford and New York: Oxford University Press, 2003, p. 261 f.; SHAPIRO, Barbara J. "Beyond Reasonable Doubt" and "Probable Cause". Historical Perspectives on the Anglo-American Law of Evidence. Berkeley: University of California Press, 1991, passim; SHEPPARD, Steve. The Metamorphoses of Reasonable Doubt: How Changes in the Burden of Proof Have Weakened the Presumption of Innocence. Notre Dame Law Rev., 2003, p. 1166 f.; WALDMAN, Theodore. Origins of the legal doctrine of reasonable doubt. Journal of the History of Ideas, 1959, p. 299 f.; WHITMAN, James Q. The origins of reasonable doubt. Theological roots of the criminal trial. New Haven: Yale University Press, 2008, passim. 
attention within legal literature and case-law towards this principle, due to the legislative reform of the Italian Code of Criminal Procedure (hereinafter CCP).

In the point of fact, the Italian Law No. 46, February 20, 2006, by amending Art. 533, ph. 1, CCP, has explicitly stated that the Judge renders a decision against the defendant in the criminal proceedings «if the accused is found guilty of the alleged offence beyond any reasonable doubt». Hence, the Italian legislator has explicitly and solemnly included in the criminal procedure code the judgment criterion of "beyond any reasonable doubt" as a negative condition of the conviction against the accused.

In particular, from a logical-textual point of view, in the Italian codicistic discipline the BARD rule is formulated in a "negative" way (i.e. paying attention to the evidentiary situation that legitimizes the condemnation of the accused) and not in a "positive" way (that is to say in the perspective of the evidence that determines the acquittal), because - according to the traditional distribution of the onus probandi in the criminal proceeding - it is up to the prosecution to bring such evidence as to eliminate any reasonable doubt about the guilt of a defendant, who is presumed to be innocent until the contrary is proven.

Nevertheless, to the present day the evaluative criterion to establish criminal liability "beyond a reasonable doubt" is still generally characterized by substantial ambiguity and conceptual vagueness. Unfortunately, the concept of reasonable doubt is inherently complex and does not easily lend itself to definition or refinement. Therefore, in over fifteen years, in Italy the legislative introduction has not prevented a recurrence of different interpretations that mutually rebut each other in a fervid debate.

Precisely in this regard, this essay - through a careful analysis of various positions and elaborations developed in Italy by legal literature and case-law - aims to highlight that, in Italian criminal proceedings, the probatory and judgment criterion of reasonable doubt, without being reduced only to the subjective extent of judicial belief, is called to constitute (in implementation of the fundamental principle of favor innocentiae) a specific legal method of parties' evidentiary argumentation, of judge's conviction and, correlatively, of decision's rational justification. In this perspective, therefore, the reconstructive key of the reasonable doubt concept, far from postulating the need for the establishment of a static 
and abstract evidentiary standard, is based on the identification of a methodological path - capable of providing prescriptive modalities for the concrete formation of the judge's conviction - to be pursued to reach that threshold of legal certainty necessary to justify the accused's condemnation.

\section{The Italian Codification of a Common Law legal Formula.}

In some common law countries, such as the United States of America, the evidentiary and judgment rule of the "beyond a reasonable doubt" has represented for centuries a real source of pride of their democracies, as well as the cornerstone of their criminal justice.

Under careful reflection, it appears to be almost impossible to relocate without due care and necessary adjustments the BARD formula arisen and developed at the heart of common law, through a centuries-old elaboration both of legal literature ${ }^{3}$ and of case-law ${ }^{4}-$ to civil law trial

3 For an analysis of this regulatory scheme in the common law legal literature, see, in particular, ALLEN, Jessie. Blind Faith and Reasonable Doubts: Investigating Beliefs in the Rule of Law. Seattle Univ. Law Rev., 2001, p. 691 f.; CLARK, Sherman J. The Juror, the Citizen, and the Human Being: The Presumption of Innocence and the Burden of Judgment. Crim. Law and Philos., 2014, p. 421 f.; LAUDAN, Larry. Is Reasonable Doubt Reasonable?. Legal Theory, 2003, 9, p. 295 f.; LAUDAN, Larry. Truth, Error, and Criminal Law. An Essay in Legal Epistemology. Cambridge: Cambridge University Press, 2006, p. 32 f.; LILLQUIST, Erik. Recasting Reasonable Doubt: Decision Theory and the Virtues of Variability. U.C. Davis Law Rev., 2002, p. 86 f.; LIPPKE, Richard L. The Prosecutor and the Presumption of Innocence. Crim. Law and Philos., 2014, p. 337 f.; MINHAS, Azhar J. Proof Beyond any reasonable doubt: Shifting Sands of a Bedrock. Northern Illinois Univ. Law Rev., 2003, p. 46 f.; NEWMAN, John O. Beyond "Reasonable Doubt". New York Univ. Law Rev., 1993, p. 984 f.; RAMADAN, Hisham M. Reconstructing Reasonableness in Criminal Law: Moderate Jury Instruction Proposal. Journal of legislation, 2003, p. 233 f.; RAMADAN, Hisham M., The Challenge of Explaining "Reasonable Doubt". Criminal Law Bulletin, 2004, p. 65 f.; ROBERTS, Paul; ZUCKERMAN, Adrian. Criminal Evidence, II ed., Oxford and New York: Oxford University Press, 2010, p. 366 f.; STEIN, Alex. Foundations of Evidence Law. Oxford and New York: Oxford University Press, 2005, p. 172 f.; WRIGHT, Richard W. Causation, Responsibility, Risk, Probability, Naked Statistics and Proof: Pruning the Bramble Bush by Clarifying the Concepts. Iowa Law Rev., 1988, p. 1002.

4 In particular, regarding the exact content of the numerous case-law decisions that in the United States have succeeded one another and have faced this 
systems, where the administration of criminal justice is based on the formulation of reasoned decisions with grounds stated by professional Judges, and not on groundless verdicts issued by juries.

In truth, whereas a judicial system based on a jury poses the crucial problem of ensuring that a fair state of mind of the jurors, an "abiding conviction" on the criminal liability of the accused, is reached, in the Italian criminal procedural law the pure and simple personal belief of the Judge is irrelevant. What matters is the rational acceptability of the decision, as expressed in the pars motiva of the judgement ${ }^{5}$.

vexata quaestio, it is possible to ideally surmise an essential distinction: on the one hand, there are those judgments focusing on highlighting the ethical and political values expressed by the "beyond a reasonable doubt" rule [(In re Winship, 397 U.S. 358 (1970); Victor v. Nebraska, 512 U.S. 1 (1994); Foucha v. Louisiana, 504 U.S. 71 (1992); Arizona v. Fulminante, 499 U.S. 279 (1992); Medina v. California, 505 U.S. 437 (1992)]; on the other hand, there are conspicuously more important, diversified, and complex judgments that also aim at identifying the conceptual entity and the material elements of the heuristic formula of BARD [McCullough v. State, 99 Nev. 72, 75, 657 P.2d 1157, (1983); Sullivan v. Louisiana, 508 U.S. 257 (1993); Jones v. United States, 526 U.S. 227 (1999); Moran v. Ohio, 469 U.S. 984 (1984); Cage v. Louisiana, 498 U.S. 39 (1990); The people of the State of California $v$. Orenthal James Simpson, No. Ba097211 (1995); Almendarez-Torres v. United States, 523 U.S. 234 (1998); Jones v. United States, 526 U.S. 227 (1999)].

5 Indeed, in judicial systems with a common law jury the fundamental point is to safeguard that a correct mental state of the judging body is formed, while the cognitive process culminating in the verdict cannot be really verified. On the contrary, in many continental Europe countries, such as Italy, the judicial system, foremost, requires that the judge demonstrate that he has not let himself be overcome by prevention and sentiment, as well as that he has not let himself be carried away by impulse and uncontrolled intuition. Furthermore, this kind of jurisdictional system wants the judge to demonstrate how he reached his conviction and the evidence used in the argumentative procedure, so explaining in the judgment motivation the logical process followed and how evidentiary elements were assessed with a positive or negative value. In this regard, see JONAKAIT, Randolph N. The American Jury System. New Haven and London: Yale University Press, 2003, p. 2 f.; LANGBEIN, John H. op. cit., p. 321 f.; NAJDOWSKI, Cynthia J.; STEVENSON, Margaret C. (ed.). Criminal juries in the 21st century. Contemporary issues, psychological science, and the law. New York: Oxford University Press, 2019, p. 19 f.; VIDMAR, Neil (ed.). World Jury Systems. Oxford and New York: Oxford University Press, 2000, p. 23 f. 
By way of explanation, in common law trial systems, while it is not possible to assess the cognitive process resulting in the verdict, the type of information provided to the jury is easy to control. Conversely, within the Italian criminal justice system, the Judge's task must be transferred in a precise and cogent legal ground for the taken decision. As a matter of fact, in light of the legislative provision, the judgment must be first and foremost expressed «specifying the reached results and the adopted criteria in the grounds of the judgment» (Art. 192, ph. 1, CCP). Furthermore, even after the recent approval of the Law No. 103, June 23, 2017, the reasons adduced for a judgment must be necessarily stated in a binary structure in which concisely the evidence fundamental for the decision and the «explanations on why the evidence in rebuttal are deemed to be unreliable» (with particular regard to some points expressly specified ex lege) are both indicated (Art. 546, ph. 1, Lett. $\mathrm{E}, \mathrm{CCP}$ ). The aim of all this is to legitimize, in a thorough manner, the judicial compliance with a determined historical reconstruction and the rebuttal of opposing hypotheses ${ }^{6}$.

Certainly, the meaning of "reasonable doubt" as codified in the California Penal Code ${ }^{7}$ and mentioned in the California Criminal Jury

6 In this regard, see CERESA-GASTALDO, Massimo. Nuovi (discutibili) profili dell'inammissibilità delle impugnazioni. In: BARGIS, Marta; BELLUTA Hervé (ed.). La riforma delle impugnazioni tra carenze sistematiche e incertezze applicative (Commento alla legge 23 giugno 2017, n. 103 e al d.lgs. 6 febbraio 2018, n. 11). Torino: Giappichelli, 2018, p. 11 f.; CAPONE, Arturo. La motivazione della sentenza. In: GIULIANI, Livia; ORLANDI, RENZO (ed.). Indagini preliminari e giudizio di primo grado. Commento alla legge 23 giugno 2017, n. 103. Torino: Giappichelli, 2018, p. 297 f.; DELLA MONICA, Giuseppe. Contributo allo studio della motivazione. Padova: Cedam, 2002, p. 98 f.; IACOVIELLO, Francesco Mauro. La motivazione della sentenza penale e il suo controllo in cassazione. Milano: Giuffrè, 1997, p. 226 f.; IACOVIELLO, Francesco Mauro, Lo standard probatorio dell'al di là di ogni ragionevole dubbio e il suo controllo in cassazione. Cassazione Penale, 2006, p. 3874; MENNA, Mariano. La motivazione del giudizio penale. Napoli: Jovene, 2000, p. $61 \mathrm{f}$.

7 Of course, a definition of reasonable doubt, representing a cornerstone of the conceptual evaluation in common law, is reached in the California Penal Code Section 1096: «it is not a mere possible doubt; because everything relating to human affairs is open to some possible or imaginary doubt. It is that state of the case, which, after the entire comparison and consideration of all the evidence, leaves the minds of jurors in that condition that they cannot say they feel an abiding conviction of the truth of the charge». 
Instructions has the absolute merit of binding, concretely and indissolubly, the «abiding conviction» with the «entire comparison and consideration of all the evidence». Nevertheless, it is not easy to contest that «considering all the evidence and weighing it in an appropriate way are very distinct things»8. This formula atones also for its shortcoming of focus on the subjective state of the juror, suggesting very little about the kind of evidence necessary for conviction, but above all ignoring the process of reasoning trough the evidence altogether.

After all, this might be one of the salient points leading today towards an increasingly open discussion about the BARD "failure" in the common law experience ${ }^{9}$. In other words, the problem lies not so much in the undeniable hurdle of understanding and formalizing a notion of "reasonable doubt" that overcomes the objective ambiguity and the succinctness of this linguistic and conceptual formula ${ }^{10}$, but rather in

8 LAUDAN, Larry. Is Reasonable doubt Reasonable?, loc. cit., p. 305.

9 Laudan expressly states, categorically and from different points of view, that «BARD is failing», so much so that he efficaciously concludes the following: «BARD's day has come and gone» (Truth, Error, and Criminal Law. An Essay in Legal Epistemology, loc. cit., p. 51 and 62). For a coherent critique of Laudan's speculative position in subiecta materia, see STELLA, Federico; GALAVOTTI, Maria Carla. «L'oltre il ragionevole dubbio» come standard probatorio. Le infondate divagazioni dell'epistemologo Laudan. Rivista italiana di diritto e procedura penale, 2005, p. $883 \mathrm{f}$.

10 It is interesting to note that a particular interpretation claims the concept of "reasonable doubt" to be self-evident or self-defining, and, therefore, already existing in the minds of the jurors. It is, hence, maintained that a prior definition, provided in the jury instructions, explaining the level of proof necessary to consider an accused guilty of a specific crime, is superfluous, or even inopportune and harmful: "reasonable doubt" must speak for itself. Jurors know what is "reasonable" and are quite familiar with the meaning of "doubt" Judges' and lawyers' attempts to inject other amorphous catch-phrases into the "reasonable doubt" standard, such as "matter of the highest importance", only muddy the water. It is, therefore, inappropriate for judges to give an instruction defining "reasonable doubt", and fit is equally inappropriate for trial counsel to provide their own definition» (U.S. v. Glass, 846 F.2d 386, 1988). On closer inspection, nevertheless, this stand seems to be justified by the objective difficulty in formalizing a notion of this concept that could be largely embraced, rather than by the real existence of an immediate and general notion of a univocal meaning of the saying "reasonable doubt". In truth, it was noted that «the term "beyond a reasonable doubt" may be in common usage by the populace of this nation, but there is no demonstrable or reliable evidence that a reasonably appropriate 
the - more or less - obstinacy of legal practice and theory that keep on defining it in terms of target mental state of the jurors, thus leaving in a cryptic perspective the epistemic relevance of adversarial principle, probatory inferences, the assessment of alternative hypotheses, and the connections between evidence and final decision, hence, the whole dynamic aspect of the cognitive material operation ${ }^{11}$. On the other hand, the idea according to which «it is not essential that a juror be able to give "some proper reason for entertaining it"; it may exist without his being able to formulate any reason for it» ${ }^{12}$ - typical of the common law tradition appears to be intrinsically structured in a judicial system based on a verdict lacking the obligation to state grounds for it. In so reasoning, however, it is unchallengeable that «if a juror's doubt cannot be expressed, we cannot parse it along the axis that separates the rational from the irrational» ${ }^{13}$.

Therefore, an effective and adequate reconstruction of the formula transplanted from the common law tradition to the criminal procedure code in force will have to confront the distinctive features of the Italian legal experience, in which this procedural institution - far from coming to a decision only according to the subjective measure of the Judge's belief - is basically held liable for the creation of a legal method for the parties' argumentations, the cognition of the judicial body, and the rational explanation on the adopted decisions. When facing the codification of

definition is in common usage or well understood by prospective citizen jurors» (Concurring opinion by Anderson, in U.S. v. Witt, 648 F.2d 608, 612, $9^{\text {th }}$ Cir. 1981). Furthermore, it should be noted that in the English system, where the criterion of beyond a reasonable doubt was coined, is currently practice to avoid explanations and clarifications on the material content of this rule, as such practice is deemed to negatively influence the juries.

11 It is no coincidence that LAUDAN, Larry. Is Reasonable Doubt Reasonable?, loc. cit., p. 305, in relation to the centuries-old and invincible «fundamental conceptual confusion» on BARD and on the consequential problematic nature of its applicability, expressively recalls the importance to focus this rule on the proofs necessary to justify a well-founded belief, stating also that «instead of instructing jurors as to what mental state they should have in order to vote to convict, courts would do better to inform jurors in a general way about the epistemic or logical features that a case must exhibit before it can properly be regarded as putting the accused's guilt beyond reasonable doubt».

12 Pennsylvania v. Dauphinee, 121 Pa. Super. 565, 590 (1936).

13 LAUDAN, Larry. Is Reasonable Doubt Reasonable?, loc. cit., p. 308. 
the probatory and judgment criterion characterizing the Anglo-American world, legal professionals have to deal with the impact of this innovation in the Italian justice system, as well as especially acknowledging, steering, and developing the strong correlation established between the "beyond any reasonable doubt" criterion and the dynamic structures of the criminal procedure adopted in Italy, where the burden of proof borne by the prosecution adds up to the obligation to state grounds for the judicial decisions ${ }^{14}$.

In the wake of the 2006 reform, a position emerged in the legal literature, aiming at minimizing the real enlightening significance of this new regulation ${ }^{15}$ by supporting the nature of acknowledgement

${ }^{14}$ On the merits, it is interesting to notice that, according to the jurisdiction of the International Criminal Court, if on the one hand the Rome Statute establishes that, «in order to convict the accused, the Court must be convinced of the guilt of the accused beyond reasonable doubt» (Art. 66, ph. 3, SCPI), on the other hand, it provides that «the decision shall be in writing and shall contain a full and reasoned statement of the Trial Chamber's findings on the evidence and conclusions» (Art. 74, ph. 5, SCPI). In this regard, in particular, see FANCHIOTTI, Vittorio. Il giudizio. In: LATTANZI, Giorgio; MONETTI, Vito (ed.). La Corte penale internazionale. Organi - Competenza - Reati - Processo. Milano: Giuffrè, 2006, p. 1221 f.; FANCHIOTTI, Vittorio; MIRAGLIA, Michela; PIERINI, Jean Paul. La Corte penale internazionale. Profili sostanziali e processuali. Torino: Giappichelli, 2014; SCHABAS, William A. The International Criminal Court. A Commentary on the Rome Statute, II ed., Oxford: Oxford University Press, 2016, p. 1635 f.; VAGIAS, Michail; FERENCZ, Janos. Burden and Standard of Proof in Defence Challenges to the Jurisdiction of the International Criminal Court. Leiden Journal of International Law, 2015, 28, 1, p. $133 \mathrm{f}$.

15 For an interpretation towards a mitigation of the innovative scope of the reform, see F. D'ALESSANDRO, L'oltre ogni ragionevole dubbio nella valutazione del nesso causale e della colpa: passi avanti della più recente giurisprudenza di merito e di legittimità. Cassazione penale, 2006, p. 2406; V. GAROFOLI, I nuovi standards valutativi e gli epiloghi decisori nel giudizio. In: A. GAITO (ed.). La nuova disciplina delle impugnazioni dopo la "legge Pecorella". Torino: Utet, 2006, p. 77 f.; G. ILLUMINATI, Giudizio. In: CONSO, Giovanni; GREVI, Vittorio; BARGIS, Marta. Compendio di procedura penale, IX ed., (Padova: Cedam, 2018, p. 882; LOZZI, Gilberto. Lezioni di procedura penale, XIV ed., Torino: Giappichelli, 2020, p. 599; PAPAGNO, Claudio. L'interpretazione del giudice penale tra regole probatorie e regole decisorie. Milano: Giuffrè, 2009, p. 349; PERCHINUNNO, Vincenzo. La fase del giudizio. In: PISANI, Mario; MOLARI, Alfredo; PERCHINUNNO, Vincenzo; CORSO, Piermaria; DOMINIONI, Oreste; GAITO, Alfredo; SPANGHER, Giorgio. Manuale di procedura penale, VIII ed., Bologna: Monduzzi, 2008, p. 508; PISANI, Mario. Riflessioni 
of a judgment rule already existing in the criminal justice system and, most of all, highlighting its abstract and programmatic nature for being a mere "token law"16.

It was stated that BARD was already an immanent rule in the Italian procedural law, as it naturally accompanies the basic principle of the presumption of innocence ${ }^{17}$. Art. 27, ph. 2 of the Italian Constitution (as well as by the more "precise" provision set forth in Art. 6, ph. 2, $\mathrm{ECHR}^{18}$ ), in particular, already provided the grounds for this guarantee criterion by considering that the persistence of any reasonable doubt on the defendant's responsibility could never have allowed surmounting the obstacles of such guarantee. In support of the preexistence of the principle introduced by the 2006 reform of Art. 533, ph. 1, CCP in the Italian legal order, it has been especially emphasized that the codification of the "beyond any reasonable doubt" rule appears to be quite redundant,

sul tema del "ragionevole dubbio". Rivista italiana di diritto e procedura penale, 2007, p. 1253 f.; TRIGGIANI, Nicola. Lo standard dimostrativo nella decisione di colpevolezza. In: INCAMPO, Antonio; SCALFATI, Adolfo (ed.). Giudizio penale e ragionevole dubbio. Bari: Cacucci, 2017, p. 327 f.; UBERTIS, Giulio. Fatto, prova e verità (alla luce del principio dell'oltre ogni ragionevole dubbio). Criminalia, 2009, p. 327.

On this point, CORDERO, Franco. Procedura penale, VIII ed., Milano: Giuffrè, 2006, p. 1001, spoke in a critical way about a "banal Americanism" and "obvious truth", considering the coded formula to be downright emphatic and unrealistic.

17 On the same conclusion, see CAPRIOLI, Francesco. item "Condanna" (diritto processuale penale), in Enciclopedia del diritto, Ann. II, tome I, 2008, p. 103; FERRUA, Paolo. Il giudizio penale: fatto e valore giuridico. In: FERRUA, Paolo; GRIFANTINI, Fabio M.; ILLUMINATI, Giulio; ORLANDI, Renzo. La prova nel dibattimento penale, IV ed., Torino: Giappichelli, 2010, p. 381; KOSTORIS, Roberto E. item "Giudizio" (diritto processuale penale), in Enciclopedia giuridica Treccani, vol. XV, 1997, p. 9 f.; KOSTORIS, Roberto E. Le modifiche al codice di procedura penale in tema di appello e di ricorso per cassazione introdotte dalla cd. "legge Pecorella". Rivista diritto processuale, 2006, p. 642; PAULESU, Pier Paolo. item "Presunzione di non colpevolezza", in Digesto penale, vol. IX, 1995, p. 694.

18 On the same subject, see in particular CHIAVARIO, Mario. Sub Art. 6. In: BARTOLE, Sergio; CONFORTI, Benedetto; RAIMONDI, Guido (ed.). Commentario alla Convenzione europea per la tutela dei diritti dell'uomo e delle libertà fondamentali. Padova: Cedam, 2001, p. 153, and APRILE, Ercole. Diritto processuale penale europeo e internazionale. Padova: Cedam, 2007, p. 185 f. 
since it was already stated in Art. 530, ph. 2, CCP, which expressively imposes the acquittal of the defendant, should the evidence be insufficient or contradictory ${ }^{19}$.

The trend in denying a true innovative value of the terms expressed in Art. 533 of the CCP could initially be found also in caselaw. The first judgments of the Supreme Court after the entry into force of Law No. 46/2006 have acknowledged a mere descriptive nature of the legislative formula and maintained that the "reasonable doubt" on the guilt of the accused would already have entailed the acquittal pursuant to Art. 530, ph. 2, $\mathrm{CCP}^{20}$. The Court of Cassation has also pointed out that the legislator - by introducing the principle according to which a Judge renders an adverse decision only if the accused is found to be "guilty of the alleged crime beyond any reasonable doubt» - did not intend to decree a different and stricter criterion to evaluate the evidence ${ }^{21}$, insofar as Law No. 46/2006 has simply formalized a rule that was already absorbed by the case-law, and according to which a conviction is possible only if during the proceedings emerges the certitude of the defendant's liability ${ }^{22}$.

19 In particular, see DIDONE, Antonio. La c.d. "Legge Pecorella" e i giudizi pendenti in cassazione: prime riflessioni. Cassazione penale, 2006, p. 391.

20 Court of Cassation, I Division, June 28, 2006, Volpon, in Electronic Documentation Centre of the Court of Cassation, No. 234374; Court of Cassation, II Division, April 21, 2006, Serino, ib., No. 233785; in compliance with Court of Cassation, II Division, November 9, 2012, in Rivista italiana di diritto e procedura penale, 2014, p. 361.

21 For the reasons that pushed the Italian legislator to code the judgment rule of the "beyond any reasonable doubt", see CATALANO, Elena Maria. Ragionevole dubbio e logica della decisione. Alle radici del giusnaturalismo processuale. Milano: Giuffrè, 2016, p. 43 f.; CONTI, Carlotta. Al di là del ragionevole dubbio. In: SCALFATI, Adolfo (ed.). Novità su impugnazioni penali e regole di giudizio. Legge 20 febbraio 2006, n. 46, “legge Pecorella”. Milano: Ipsoa, 2006, p. 87; DALIA, Gaspare. Convincimento giudiziale e ragionevole dubbio. Milano: Wolters Kluwer, 2018, p. 7 f.; MARZADURI, Enrico. Sub Art. 5 1. 20 febbraio 2006 n. 46. Legislazione penale, 2007, p. 88 f.; RUGGIERI, Francesca. Beyond any reasonable doubt: una matrice di common law. In: INCAMPO, Antonio; SCALFATI, Adolfo (ed.). Giudizio penale e ragionevole dubbio, loc. cit., p. 307 f.

22 Court of Cassation, I Division, May 11, 2006, Ganci, in Electronic Documentation Centre of the Court of Cassation, No. 234111. Indeed, in many judgments of the Supreme Court, rendered when the original formulation of Art. 533 was still into force, it is possible to come upon more or less explicit references to the "reasonable doubt" rule defined as criterion, as can be gathered 
A different interpretation soon emerged within the complex debate on the real effects of the reform of Art. 533, ph. 1, CCP, aiming at representing the codification of the "beyond any reasonable doubt" principle if not as some sort of "Copernican revolution" in the trial assessment of the facts and of the criminal liability ${ }^{23}$, at least as a regulatory corroboration - according to the perspective of the completion of the adversarial procedure ${ }^{24}$ and strengthening of the guarantees provided by a "fair trial" - of a specific epistemological statute.

Although admitting that the prove on the "reasonableness" of the doubt can rely on complicated judgments of value ${ }^{25}$, the idea of reducing this essential characteristic to a mere issue of personality that expresses generically the outcome of a judgment balancing the

from Art. 530, ph. 2, CCP, pursuant to which, should the evidence of guilt be insufficient or contradictory, the accused must be acquitted. To this end, see Court of Cassation, IV Division, January 23, 2002, Orlando, in Rivista penale, 2002, p. 671 f.; Court of Cassation, IV Division, September 25, 2001, Covili, in Rivista italiana di diritto e procedura penale, 2002, p. $737 \mathrm{f}$. On the other hand, when the repealed code of procedure was still into force, it was possible to understand the idée en germe of this rule of judgment in some rare decisions of the Court of Cassation (Court of Cassation, I Division, July 1, 1987, Ingemi, in Cassazione penale, 1998, p. 1845; Court of Cassation, I Division, May 4, 1987, Lombardi, in Rivista penale, 1988, p. 512; Court of Cassation, I Division, April 27, 1987, Mazzotta, in Cassazione penale, 1988, p. 1699; Court of Cassation, V Division, December 12, 1975, Giannetta, in Electronic Documentation Centre of the Court of Cassation, No. 133816).

See PALIERO, Carlo Enrico. Il «ragionevole dubbio» diventa criterio, Guida al diritto, 2006, 10, p. 73; in the same vein, see PIERGALLINI, Carlo. La regola dell'"oltre ragionevole dubbio" al banco di prova di un ordinamento di civil law. Rivista italiana di diritto e procedura penale, 2007, p. $593 \mathrm{f}$.

For the codification of the "beyond any reasonable doubt" criterion as adjustment measure of the Italian trial system to the standard of the adversarial model, see CARLIZZI, Gaetano. Libero convincimento e ragionevole dubbio nel processo penale. San Lazzaro di Savena: Bonomo, 2018, p. 10 f.; GUALTIERI, Piero. Diritto di difesa e prova scientifica. Diritto penale e processo, 2011, p. 494; LORUSSO, Sergio. La regola del "ragionevole dubbio" e la riforma delle impugnazioni. In: GAROFOLI, Vincenzo (ed.). La sentenza della corte costituzionale 6 febbraio 2007, n. 26: un energico richiamo al metodo della giurisdizione, Atti del Convegno, Trani, 2-3 febbraio 2007. Milano: Giuffrè, 2007, p. 95.

25 See FERRUA, Paolo. La colpevolezza oltre ogni ragionevole dubbio. In: FILIPPI, Leonardo (ed.). Il nuovo regime delle impugnazioni tra Corte costituzionale e Sezioni unite. Padova: Cedam, 2007, p. 144. 
blatancy of the inculpating evidence and the abstract admissibility of the doubt does not seem to be shareable. The logical characteristic of "reasonableness" provides the doubt with the tangible and objective practicality nature avoiding that the outcome of the trial rests upon discretionary appreciations verging on a mere personal choice ${ }^{26}$.

Any nihilistic tendency to a skepticism portraying the "reasonableness" as an intrinsically indeterminate and fatally impossible to be determinate concept must be warden off, together with the approximate idea that it represents a datum perfectly intelligible through our most common intuition, as if it were a pure and simple feature of balance and moderation. In reality, in subiecta materia, "reasonableness" concept constitutes a rationality paradigm regarding a practical explanation, that is to say a logical pattern related to the issue of stating grounds as well as - and above all - to the intersubjective communication, control, and acceptability of these grounds during the proceedings. It is an argumentative rather than demonstrative (typical of the episteme) rationality that substantiates a justifying model aiming at making the reasons universal (rational acceptability) ${ }^{27}$.

In truth, the codification of the "beyond any reasonable doubt" evidentiary and judgment rule neither represents a useless frill, nor even an "Americanism", but it constitutes an opportune (or at least clarifying) additional intervention with the aim of filling the vast "black hole" 28 left in the code of procedure of 1988 (that is to say the incomplete formulation

26 On the other hand, the new literal formulation of Art. 533, ph. 1, CCP, associating the guilt decision to the fact that the accused is "found to be", and not "deemed to be" guilty beyond any reasonable doubt, clearly alludes to the objective level of reasonableness of the responsibility analysis, rather than to the more or less relevant subjective levels of the deemed validity of the allegation (see F. Caprioli, L'accertamento della responsabilità penale "oltre ogni ragionevole dubbio”, Rivista italiana di diritto e procedura penale, 2009, p. 65).

27 On the merits, see STELLA, Federico. Giustizia e modernità. La protezione dell'innocente e la tutela delle vittime, III ed., Milano: Giuffrè, 2003, p. 169; MARZADURI, Enrico. Il mutamento delle scienze processualistiche. L'unità del sapere penalprocessualistico. In: GAROFOLI, Vincenzo (ed.). L'unità del sapere giuridico tra diritto penale e processo, Atti del Convegno. Bari, 21-22 maggio 2004. Milano: Giuffrè, 2005, p. 88, and TARUFFO, Michele. La prova dei fatti giuridici. Nozioni generali. Milano: Giuffrè, 1992, p. 368.

28 See STELLA, Federico, op. cit., p. 141. 
of Art. 530, ph. 2, CCP), an intervention that determines ope legis a general criterion of discernment - objective (i.e. existing per se as it is not bound to the mere subjective perception) and preceptive (i.e. not left to the good conscience of each Judge) - to identify an insufficient or contradictory probatory outcome.

Therefore, it appears that it is not possible to endorse the eminent and evocative doctrinal theory that aims at reducing the significance of the coded formula to a purely connotative-didactic value, as if it were a simple invitation from the legislator to urge upon the Judge caution and severity in evaluating: a sort of standard of caution, an ethical principle with a benefic pedagogical effect, as a strong reference to the need for the conviction to be the result of a prudent and circumspect examination of evidence ${ }^{29}$. It is easy to object that by simply shaping the "beyond any reasonable doubt" rule as a principle falling outside of the legal framework - on the basis of which the trier of fact can convict someone only if sure about the defendant's guilt - the issue of having an objective standard to assess the evidence is moved to an essentially subjective dimension, in light of the fact that the caution addressing the Judge's ethical behavior concerns his personal belief, and appears to refer to the individual and irrational intime conviction of the French, rather than a rational assessment of evidence ${ }^{30}$.

The reference, in first instance, to the assessment of a criminal liability "beyond any reasonable doubt" certainly removes all juridical value in the criminal judgment from the purely skeptic doubt, that is that doubt lacking any specific motive referred to what we have reason to think in given circumstances ${ }^{31}$.

Secondly, the BARD legal formula is needed to reiterate the essentially "probabilistic" nature of the guilty judgment, given that the

29 See FERRUA, Paolo. La colpevolezza oltre ogni ragionevole dubbio, op. cit., p. 141. In this sense, see also DANIELE, Marcello. Una prima applicazione giurisprudenziale della regola dell'al di là di ogni ragionevole dubbio. Rivista di diritto processuale, 2007, p. 254.

30 See TARUFFO, Michele. Fatto, prova e verità (alla luce del principio dell'oltre ogni ragionevole dubbio). Criminalia, 2009, p. 310.

31 See MARCONI, Diego. Per la verità. Relativismo e filosofia. Torino: Einaudi, 2007, p. 25. 
evidentiary reasoning generates conclusions providing information that is not necessarily wholly included in the preambles. For these reasons, on the judgment of guilt it is never possible to confer complete certainty, but a more or less substantial probability degree ${ }^{32}$. Naturally, such "probability" is not merely quantitative, but it is a logical relationship between available evidence and the allegations to be verified.

Nevertheless, there is a quid pluris in the legislative formula coded in 2006: the introduction in the Italian criminal trial system of the "beyond any reasonable doubt" judgment rule does not call for a static (quite obvious and politically correct) evidentiary standard with reference to the gnoseological judicial ascertainment of guilt ${ }^{33}$. This rule codification, completing a multiannual legislative, academic and jurisprudential effort, aims at creating a legal method (but not a legalistic one) of juridical reasoning in the discriminating evaluation of proof and rational justification of the adopted decision.

When experiencing the reality of the Italian criminal trial system, one must inspect the substantial nature of the "beyond any reasonable

32 See FESTA, Roberto. Induzione, probabilità e verisimilitudine. In: GIORELLO, Giulio (ed.). Introduzione alla filosofia della scienza, II ed., Milano: R.C.S., 1999, p. 285.

33 On the merits, KOSTORIS, Roberto E., item "Giudizio" (diritto processuale penale), loc. cit., p. 13, points out that it is impossible to define in the abstract the exact threshold according to which the evidence must be considerate as sufficient to justify a statement of guilt. Furthermore, in legal literature there is the belief that Art. 533, CCP establishes the qualitative standard required as proof of the defendant's criminal liability, i.e. the threshold of certitude to which the evidence obtained during the proceedings must aim for in order to render a conviction (see DELLA MONICA, Giuseppe. Il principio del libero convincimento. In: CATALANO, Elena Maria; CURTOTTI NAPPI, Donatella; DELLA MONICA, Giuseppe; LORUSSO, Sergio; MONTAGNA, Mariangela; PROCACCINO, Angela. Prova penale e metodo scientifico. Torino: Utet, 2009, p. 211; in the same vein, FERRUA, Paolo. Giusto processo: l'attuazione si misura con le incertezze della giurisdizione. Diritto e giustizia, 2001, 26, p. 31; LORUSSO, Sergio. La prova scientifica. In: GAITO, Alfredo (directed by), La prova penale, vol. I, Torino: Utet, 2008, p. 341). Nevertheless, on a closer inspection, if the "reasonable doubt" is basically intended as a standard to overcome for the defendant's conviction, the attention is brought on the an of the rational acceptability of the decision, whereas the dynamic aspect of the quomodo of such overcoming during the evaluative and decisional phase of the proceedings remains overshadowed. 
doubt", that is to say its objective projection and the operative schemes that can help the judicial implementation of this rule ${ }^{34}$. This is the only way to bring out the mainly dynamic nature of the functional interaction between the evidentiary and judgment rule under discussion and the inner conviction of the Judge, considering, in prospect, the subsequent activity of logically and juridically supporting it in the grounds of the judgment ${ }^{35}$.

\section{3. "Beyond any Reasonable Doubt" as Evidentiary and Judicial Rule in the Italian Criminal Trial.}

Even before the codification of the "beyond any reasonable doubt" criterion, it is possible to observe how the most mindful Italian case-law never backed out from the intellectual effort to formalize the modus operandi of this rule. Nonetheless, this case-law has taken good care of avoiding getting stuck in abstract schemes or sterile algorithms, and never rested upon the illusion of magic or miraculous formulae. The attention on the effort to provide a concrete meaning to the "reasonable doubt" concept focused on the field of the scientific evidence, which has always brought about cognitive problems that tend to overcome the common experience, and that request more solid grounds for the guilty decision.

Many Supreme Court decisions (such as the "Franzese" case) did not limit themselves to apodictically stating that insufficient, contradictory or uncertain evidence - that is to say the disclosure of the "reasonable doubt" - entails the neutralization of the charges and the consequent acquittal, but rather tried to elucidate the evidential reasoning that must lead to the guilty verdict. After having differentiated the statistical

34 In this sense, PAULESU, Pier Paolo. La presunzione di non colpevolezza dell'imputato, II ed., Torino: Giappichelli, 2009, p. 192, stressed that the already made codification of the "beyond any reasonable doubt" judgment rule set forth in Art. 533, ph. 1, CCP does not solve, but rather raises a problem on the decision about an uncertain fact that can find today, as in the past, an adequate solution only in terms of interpretation; as a consequence, he hoped for the determination of some conceptual coordinates that can be "reasonably" shared.

See FERRUA, Paolo. La colpevolezza oltre ogni ragionevole dubbio, op. cit., p. 145 . 
probability (relevant to the «empiric verification of the frequency regarding the sequence of events») from the logical probability (that «by following the inductive advancement of the evidential reasoning to establish the degree of confirmation of the alleged hypothesis on a specific circumstance to be proven, it includes the additional verification, on the grounds of the whole available evidence, [...] of the persuasive and rational credibility of the judicial ascertainment»), this decision has highlighted how, within criminal proceedings, the logical method must lead to a conclusion showing a "high degree of rational credibility", hence to the "trial certainty" » so that «the interference of different developments is avoided $»^{36}$.

Recently, Judges of the Supreme Court have specified in some judgements that, pursuant to the new statement of Art. 533, ph. 1, CCP, it is mandatory to pass a conviction when the obtained evidence leaves out only the remote possibility that, even if expressible in abstract and imaginable as possible in rerum natura, does not find the slightest validation when compared to trial findings, thus standing outside the natural order of things and of the normal human rationality ${ }^{37}$.

Certainly, these well-structured propositions cannot sum up the whole systemic operating process of the "beyond any reasonable doubt" criterion. In any case, even if still undeniably perfectible, they have the unquestionable merit of focusing on a distinctive connotation

36 Court of Cassation, Joint Chambers, July 10, 2002, Franzese, in Cassazione Penale, 2002, p. 3643 (trans. vers.).

37 See Court of Cassation, I Division, May 21, 2008, Franzoni, in Cassazione penale, 2009, p. 1840; Court of Cassation, I Division, May 26, 2010, Erardi, in Diritto penale e processo, 2011, p. 23; Court of Cassation, II Division, December 19, 2014, Segura, in Electronic Documentation Centre of the Court of Cassation, No. 262280; Court of Cassation, IV Division, February 19, 2016, in Guida al diritto, 2006 (29), p. 62; Court of Cassation, I Division, April 12, 2016, in Electronic Documentation Centre of the Court of Cassation, No. 266941; Court of Cassation, IV Division, May 3, 2016, in Diritto e giustizia, 2016; Court of Cassation, VI Division, December 6, 2016, S.M., in Diritto penale e processo, 2017, p. 309; Court of Cassation, VI Division, January 17, 2017, in Giurisprudenza italiana, 2018, p. 468; Court of Cassation, VI Division, February 14, 2017, Albano, in Electronic Documentation Centre of the Court of Cassation, No. 270299; Court of Cassation, IV Division, June 19, 2018, Castelli, ib., No. 274358; Court of Cassation, V Division, November 12, 2018, Segreto, ib., No. 275299; Court of Cassation, I Division, November 18, 2020, S., ib., No. 280605. 
of this regulatory provision: the statement of criminal liability in terms of certainty does not exclude the presence of the most abstract and remote possibility or any verisimilitude whatsoever, but the serious possibility to advance any other reasonable solution.

Furthermore, it is even more important to note that such statements attest how the "beyond any reasonable doubt" criterion does not represent the subjective measure of the Judge's belief, but rather the objective condition of confirming the allegation on the basis of the available evidence, taken as basis for the guilty decision.

Therefore, by restating Art. 533, ph. 1, CCP, the legislator did not mean to enter the "forbidden garden" of the free conviction of the Judge, but only to overcome the traditional dichotomy between the legal evidence system and the intime conviction, in favor of a criminal justice administration that conciliates the free appraisal of the evidence with the rational predictability of the judgment ${ }^{38}$. Having coded the heuristic formula of the "beyond any reasonable doubt" means having adopted the argumentative vis of the doubt as a cognitive and communicable critical evaluation tool both of evidence and opposing allegations on the fact ${ }^{39}$.

In this respect, the "reasonableness" begins to be "the measure of all things", whereas the criminal judgment - permanently ceasing to

38 After all, the judgment rule expresses a "fundamental need for freedom", tightly bounded to the rational nature of the modern trial (see PAULESU, Pier Paolo. La presunzione di non colpevolezza dell'imputato, loc. cit., p. 180), which does not allow to leave the procedural assessment of truth to a Judge's discretionary power of decision. Hence, the codification of the "reasonable doubt" criterion is necessary to avoid the contingency that the inner conviction is transformed from typical symbol of the adversary criminal trial (see NOBILI, Massimo. Il principio del libero convincimento del giudice. Milano: Giuffrè, 1974 , p. 32) into a "crowbar in the Judge's hands" (see CORDERO, Franco, op. cit., p. 588), which would be characterized by a substantial arbitrariness.

39 Accordingly, the Judges from the Court of Cassation have also recently asserted that the "beyond any reasonable doubt" rule, introduced by Law No. 46/2006, imposes to the Judge a dialectic way of verifying the allegation according to the "doubt" criterion, so as to avoid any inner (self-contradiction or explanatory incapability) or external (existence of an alternative hypothesis provided with rationality and practical plausibility) doubts (see Court of Cassation, I Division, October 24, 2011, Javad, in Electronic Documentation Centre of the Court of Cassation, No. 251507; Court of Cassation, V Division, December 12, 2015, Stasi, in Diritto penale contemporaneo (web), June 29, 2016, p. 110). 
constitute the solipsism of the judicial body - fully becomes a dialectic dispute between the parties of the trial before an independent Judge (in medio cognoscens). In short, the criminal trial becomes an actus trium personarum [a proceedings before three different actors], in which, by means of a rigorous process of a falsifying epistemology, the allegation undergoes multiple and systematic rebuttal so as to thoroughly sift the logical coherence and the compatibility with the evidence.

Through the rule of the "beyond any reasonable doubt", as criterion for judicial assessment of evidence, the epistemological principle of the adversarial process permeates not only the evidential and reasoning procedure of the parties, but also the work of knowledge and rational explanation carried out by the Judge ${ }^{40}$. In truth, only by untangling all knots of the dialectic discussion developed during the course of the proceedings, both on antagonistic reconstructions and evidence, it is possible to have proper control on the possible alternative statement of facts capable of leading to the exclusion of a "reasonable doubt" margin on the guilt of the accused.

Finally, with one last notation, it is interesting to observe that in Italy the "beyond any reasonable doubt" criterion permeates the main lines of the criminal procedural system and gives salient expression to the cognitive status of justice in criminalibus, which gravitates around the fundamental principles of orality of trial and of immediacy in the formation of evidence.

This emerges with particular reference to the overturning of the first-instance acquittal, especially with regard to the judicial evaluation of the declarative evidence ${ }^{41}$. In fact, the BARD criterion requires generally

40 The epistemological principle of the adversarial system is translated in a tool to stimulate a thorough investigation on any advanced hypothesis, demanding attention and openness of the judicial body toward the ascertainment of any alternative potentially undermining the original formulation of the Public Prosecutor (see GAITO, Alfredo. Il procedimento probatorio (tra vischiosità della tradizione e prospettive europee). In: ID. (directed by) La prova penale, vol. I, loc. cit., p. 102).

41 On the issue of the overturning on appeal, see COPPI, Franco. No all'appello del pm dopo la sentenza di assoluzione. Il giusto processo, 2003, p. 27 f.; PADOVANI, Tullio. Il doppio grado di giurisdizione: appello dell'imputato, appello del P.M., principio del contraddittorio. Cassazione penale, 2003, p. 4023 
that, in the absence of occurred elements, any pejorative review carried out on appeal must be supported by resolutive arguments, able to highlight objective inadequacies or insufficiencies of the acquittal decision ${ }^{42}$. In other words, in case of overturning on appeal, the first-instance acquittal of the accused must be no longer sustainable, even in the sense of leaving residual reasonable doubts open on the assertion of guilt. This means that a different judicial evaluation of equivalent plausibility, with respect to the assessment of the first judge, is not enough to overturn an acquittal; on the contrary, it is necessary, on the level of the rational justification of conviction, a "superior persuasive force" ${ }^{43}$, capable of bringing down any reasonable doubt.

However, in order to realize actually a "reinforced" motivation of the overturning that achieves and supports a decision of guilt "beyond a

f.; SPANGHER, Giorgio. Sistema delle impugnazioni penali e durata ragionevole del processo. Corriere giuridico, 2002, 10, p. 1262 f.; STELLA, Federico. Sul divieto per il pubblico ministero di proporre appello contro le sentenze di assoluzione. Cassazione penale, 2004, p. 756 f.; LOZZI, Gilberto. Reformatio in peius del giudice di appello e cognitio facti ex actis della Corte di cassazione. Rivista italiana di diritto e procedura penale, 2004, p. 641 f.; PISANI, Mario. Durata ragionevole del processo penale e appellabilità delle sentenze. Rivista di diritto processuale, 2006, p. 3 f.; TRANCHINA, Giovanni; DI CHIARA, Giuseppe, item “Appello" (diritto processuale penale), in Enciclopedia del diritto, Agg. III, Milano, 1999, p. 202 f.

42 In this sense, see Court of Cassation, VI Division, November 21, 2012, in Electronic Documentation Centre of the Court of Cassation, No. 253909; Court of Cassation, VI Division, January 24, 2013, ib., No. 254113; Court of Cassation, III Division, November 27, 2014, ib., No. 262524; Court of Cassation, II Division, April 9, 2015, ib., No. 263763; Court of Cassation, V Division, September 14, 2017, ib., No. 272082; Court of Cassation, IV Division, March 14, 2017, ib., No. 269610; Court of Cassation, IV Division, January 18, 2018, ib., No. 272224.

See Court of Cassation, Joint Chambers, april 28, 2016, Dasgupta, in Electronic Documentation Centre of the Court of Cassation, No. 267486. For an analysis of this decision, see AIUTI, Valerio. Poteri d'ufficio della Cassazione e diritto all'equo processo. Cassazione penale, 2016, p. 3214 f.; CAPONE, Arturo. Prova in appello: un difficile bilanciamento. Processo penale e giustizia, 2016, p. 52 f.; LORENZETTO, Elisa. Reformatio in peius in appello e processo equo (art. 6 Cedu): fisiologia e patologia secondo le Sezioni unite. Diritto penale contemporaneo (web), October 5, 2016; TESORIERO, Salvatore. Luci e ombre della rinnovazione dell'istruttoria dibattimentale in appello per il presunto innocente. Giustizia penale, 2017, III, c. 79 f. 
reasonable doubt", it is not possible to do without orality and immediacy in the reassuming of the declarative evidence turned out to be decisive. Otherwise, the pars motiva of the judgement would be compromised by the logical aporia deriving from the fact that the overturning of acquittal, made on the basis of a mere paper valuation of the evidence available to the first judge, «contains in itself the implicit reasonable doubt determined by the adoption of conflicting decisions ${ }^{44}$. In such cases, in direct consideration of the canons of "fair trial" in criminal proceedings - contained in Art. 111 of the Italian Constitution, as well as in Art. 6 ECHR - the reasonable doubt about the accused's guilt can be overcome only by using the "best" method for forming evidence. In this sense, in 2017 the Italian legislator (Law No. 103, June 23,2017$)^{45}$ - also for the primary purpose of incorporating

${ }^{44}$ Court of Cassation, Joint Chambers, January 19, 2017, Patalano, in Electronic Documentation Centre of the Court of Cassation, No. 269786 (trans. vers.). On this point, see, in particular, APRATI, Roberta, Overturning sfavorevole in appello e mancanza del riesame. Cassazione penale, 2017, p. 2672 f.; BELLUTA, Hervé; LUPÁRIA, Luca. Ragionevole dubbio e prima condanna in appello: solo la rinnovazione ci salverà? Diritto penale contemporaneo (web), May 8, 2017; ROMBI, Natalia. Le Sezioni unite e le condanne cartolari nel giudizio abbreviato d'appello. Processo penale e giustizia, 2017, p. $806 \mathrm{f}$.

${ }^{45}$ In this regard, see AIUTI, Valerio. Obbligo di rinnovazione e prova dichiarativa. In: MARANDOLA, Antonella; BENE, Teresa (ed.). La riforma della giustizia penale. Modifiche al codice penale, al codice di procedura penale e all'ordinamento penitenziario (L.103/2017), Milano: Giuffré, 2017, p. 254 f.; BARGIS, Marta. Riforma in due fasi per la disciplina dell'appello penale. Diritto penale contemporaneo (web), June 13, 2018; BELLUTA, Hervé; LUPÁRIA, Luca. La rinnovazione dell'istruttoria dibattimentale fra legge e giurisprudenza: punti fermi... e non. Sistema penale (web), November 20, 2019; BRONZO, Pasquale. La nuova ipotesi di rinnovazione dell'istruzione dibattimentale in appello. In: BACCARI, Gian Marco; BONZANO, Carlo; LA REGINA, Katia; MANCUSO, Enrico Maria (ed.). Le recenti riforme in materia penale, Milano: Cedam, 2017, p. 413 f.; CAPRARO, Laura. Novità per l'appello: concordato sui motivi e obbligo di rinnovazione istruttoria. In: SCALFATI, Adolfo (ed.). La riforma della giustizia penale. Commento alla legge 23 giugno 2017, n. 103, Torino: Giappichelli, 2017, p. 211 f.; CAPONE. Arturo. Appello del pubblico ministero e rinnovazione istruttoria. In: BARGIS, Marta; BELLUTA, Hervé. La riforma delle impugnazioni tra carenze sistematiche e incertezze applicative (Commento alla legge 23 giugno 2017, n. 103 e al d.lgs. 6 febbraio 2018, n. 11), Torino: Giappichelli, 2018, p. 53 f.; MARANDOLA, Antonella. Prime riflessioni sul "nuovo" giudizio d'appello, Diritto penale contemporaneo, 2018, 2, p. 169 f.; MONTAGNA, Mariangela. La rinnovazione obbligatoria della prova in appello: problematiche applicative. Processo penale e giustizia, 2018, p. 1151 
in the normative provisions the indications emerged in the Strasbourg Court's case-law ${ }^{46}$ - has established that the judge provides the renewal of the trial evidentiary hearing, in the event of an appeal by the Public Prosecutor against an acquittal for reasons regarding the assessment of the declarative evidence (Art. 603, ph. 3-bis, CCP) ${ }^{47}$.

Therefore, even in this juridical dimension, the BARD formula results as a "very general criterion" of the criminal procedural system ${ }^{48}$, which constitutes, through a specific ontological and operative connotation, the "eye" through which to pass whenever a decision has to be made ${ }^{49}$.

f.; SPANGHER, Giorgio. Il “nuovo” giudizio di appello. Diritto penale e processo, 2018, p. 1329; SURACI, Leonardo. La rinnovazione del dibattimento in caso di proscioglimento. In: SPANGHER, Giorgio (ed.), La riforma Orlando. Modifiche al Codice penale, Codice di procedura penale e Ordinamento penitenziario, Pisa: Pacini, 2017, p. 262 f.

European Court of Human Rights, October 5, 2011, Dan v. Moldova, § 33; European Court of Human Rights, July 5, 2016, Lazu v. Moldova, § 40; European Court of Human Rights, February 28, 2017, Manoli v. Moldova, § 32-33; European Court of Human Rights, June 29, 2017, Lorefice v. Italy, § 45. In this regard, more recently, see European Court of Human Rights, November 10, 2020, Dan v. Moldova, (No. 2), § 47; European Court of Human Rights, October 22, 2020, Tondo v. Italy, § 38; European Court of Human Rights, March 25, 2021, Di Martino e Molinari v. Italy, § 28.

47 On this point, in particular, see Court of Cassation, IV Division, January 26, 2021, in Electronic Documentation Centre of the Court of Cassation, No. 281049; Court of Cassation, II Division, February 21, 2010, ib., No. 279146; Court of Cassation, V Division, June 18, 2018, ib., No. 274593. Moreover, de iure condendo, the Study Commission for the reform of the justice system, chaired by Giorgio Lattanzi, has recently proposed to abolish the appeal of the Public Prosecutor. This legislative proposal derives, with regard to the acquittal decisions, «from the standard of beyond any reasonable doubt, which [...] makes it logically inconceivable that the procedural certainty could be achieved after an absolution, except in the presence of vices of motivation that exclude the possibility of re-proposing the alternative assessment, and as a result of a complex and problematic renewal inquiry» (Final Report of the Study Commission, May 24, 2021 - trans. vers.).

48 See Court of Cassation, Joint Chambers, January 19, 2017, Patalano, in Electronic Documentation Centre of the Court of Cassation, No. 269786.

49 See BELLUTA, Hervé; LUPÁRIA, Luca. La parabola ascendente dell'istruttoria in appello nell'esegesi "formante" delle Sezioni Unite. Diritto penale contemporaneo, 3, 2017, p. 156. 


\section{Conclusion.}

In Italy, the BARD criterion pervades the fundamental structure of the criminal procedural system and gives significant expression to some of the principal guarantees in causis criminalibus: the presumption of innocence of the accused, the burden of evidence placed on the prosecution and the decision formula in dubio pro reo, as well as the obligation of rational justification of judgements.

Without meaning to build any abstruse heuristic paradigms, naively aiming at assimilating the quomodo of the trial knowledge to the methodological rigor of natural sciences, it is possible to state that the "beyond any reasonable doubt" criterion prevents the Judge from rendering a conviction every time that there is space left for incertitude that rests upon the inadequacy of the accusation (when the inculpating evidence does not cover all the elements constituting the criminal offence or, in any case, is invalidated by counterproofs of the same demonstrating attitude) or on the existence of an alternative hypothesis - corroborated by solid evidence - that was not neutralized on its explanatory significance.

It is not sufficient that the allegation is simply proven to be more probable, plausible, or preferable if compared to the defense position, just because it is more conform to the facts relevant to assert the guilt. The decision convicting the defendant is denied when the allegation simply prevails - regardless of its margin of advantage - in light of the fact that it must categorically impose itself on any other probable factual hypothesis reconstruction, as if it had some sort of uncontested logical supremacy on the antagonistic reconstructions regarding the circumstances sub iudice ${ }^{50}$. In this manner, the burden of proof lying

50 In this sense, the Judges of the Supreme Court uphold that the rule of the beyond any reasonable doubt permanently puts a strain on that jurisprudential orientation according to which, when facing more than one thesis in reconstructing the facts, a Judge could embrace one among them only because he deemed it to be the most probable one. This will not be allowed anymore because, in order to reach a conviction, a Judge must consider the reconstruction of the fact leading to the acquittal of the defendant as improbable, but must also believe that this alternative hypothesis is unreasonable (the hypothesis must be unreliable or lacking any corroboration) (see Court of 
with the Public Prosecutor is added to the need to rebut the opposing explanations, even if not provided with sound evidence ${ }^{51}$. On the other hand, the burden of proof lying with the defense must only highlight the existence of plausible alternatives to the one - even if proven - of the prosecutor, in order to raise a "reasonable doubt" that the facts could have occurred in a different way ${ }^{52}$. Should this be the case, the rational existence of an exclusive and univocal certainty on the allegation would be therefore undermined ${ }^{53}$.

To conclude, the Italian legislator, with the normative interpolation of 2006, intended to include unequivocally and solemnly in the criminal procedure code the BARD rule, arisen and developed in the heart of the Anglo-American legal experience. However, in Italy both legal literature and jurisprudence had to manage a complex route of normative

Cassation, IV Division, November 12, 2009, Durante, in Electronic Documentation Centre of the Court of Cassation, No. 245879; Court of Cassation, V Division, February 19, 2014, ib., No. 260409).

51 For that matter, the doubt goes in favor of the accused even when the burden of proof lies with him, that is to say when he has to convince the Judge of the existence of a favorable fact. In truth, pursuant to Art. 530, ph. 3, CCP, «if there is proof that the fact is committed under a cause of justification, a personal reason of non-liability, or when there is a doubt on the existence of both these circumstances, the Judge pronounces an acquittal». See VARRASO, Gianluca. Ragionevole dubbio e prova delle esimenti. In: INCAMPO, Antonio; SCALFATI, Adolfo (ed.). Giudizio penale e ragionevole dubbio, loc. cit., p. $339 \mathrm{f}$.

52 See Court of Cassation, VI Division, December 5, 2018, in Electronic Documentation Centre of the Court of Cassation, No. 275290; Court of Cassation, VI Division, November 12, 2019, ib., No. 277682.

53 In an interesting decision, the Court of Cassation stated that the "reasonable doubt" must be grounded on matters of fact allowing an alternative reading of the value as evidence of the same elements used for the reconstructions, taking away from the opposing interpretation the persuasive univocality (see Court of Cassation, VI Division, April 4, 2013, No. 19749). On the other hand, in a more recent judgment, the Judges of the Court of Cassation reasserted how the conviction "beyond any reasonable doubt" entails that, should an alternative reconstruction of facts be proposed, the elements confirming the accepted reconstruction hypothesis have to be identified, so as to show the un-rationality of the doubt deriving from the same opposing hypothesis (see Court of Cassation, II Division, December 10, 2013, in Electronic Documentation Centre of the Court of Cassation, No. 1405; Court of Cassation, V Division, February 21, 2014, ib., No. 16397). 
implementation. They could not benefit sic et simpliciter from the precious and stratified heritage of common law experience, but had to deal with the particular juridical reality of a civil law system, in which specific emphasis is given to the procedural guarantee of the control over the evaluative, logical and argumentative process carried out by the judge and resulting from the decision's motivation. In this regard, the legislative acceptance of the BARD criterion in the Italian adversary criminal trial - far from being reduced only to a more rigorous assessment of evidence - has resulted in a legal method of evidentiary reasoning, through which to discern between the antagonistic hypotheses of innocence and guilt. In particular, the modification to Art. 533, ph. 1, CCP represents the formal and genuine recognition of a specific legal method which elevates the dialectic strength of reasonable doubt as an instrument for evaluating evidence and assumptions about facts in the finalistic perspective of the judgment motivation.

\section{BiBLIOGRAPHY}

AIUTI, Valerio. Poteri d'ufficio della Cassazione e diritto all'equo processo. Cassazione penale, Milano, p. 3214, 2016.

AIUTI, Valerio. Obbligo di rinnovazione e prova dichiarativa. In: MARANDOLA, Antonella; BENE, Teresa (ed.). La riforma della giustizia penale. Modifiche al codice penale, al codice di procedura penale e all'ordinamento penitenziario (L.103/2017), Milano: Giuffré, 2017, p. 243.

ALLEN, Jessie. Blind Faith and Reasonable Doubts: Investigating Beliefs in the Rule of Law. Seattle Univ. Law Rev., Seattle, p. 691, 2001.

APRATI, Roberta, Overturning sfavorevole in appello e mancanza del riesame. Cassazione penale, Milano, p. 2672, 2017.

APRILE, Ercole. Diritto processuale penale europeo e internazionale. Padova: Cedam, 2007.

BRONZO, Pasquale. La nuova ipotesi di rinnovazione dell'istruzione dibattimentale in appello. In: BACCARI, Gian Marco; BONZANO, Carlo; LA REGINA, Katia; MANCUSO, Enrico Maria (ed.). Le recenti riforme in materia penale, Milano: Cedam, 2017, p. 409.

BARGIS, Marta. Riforma in due fasi per la disciplina dell'appello penale. Diritto penale contemporaneo (web), June 13, 2018. 
BELLUTA, Hervé; LUPÁRIA, Luca. Ragionevole dubbio e prima condanna in appello: solo la rinnovazione ci salverà? Diritto penale contemporaneo (web), May 8, 2017.

BELLUTA, Hervé; LUPÁRIA, Luca. La parabola ascendente dell'istruttoria in appello nell'esegesi "formante" delle Sezioni Unite. Diritto penale contemporaneo, Milano, 3, p. 151, 2017.

BELLUTA, Hervé; LUPÁRIA, Luca. La rinnovazione dell'istruttoria dibattimentale fra legge e giurisprudenza: punti fermi... e non. Sistema penale (web), November 20, 2019.

CAPONE, Arturo. Prova in appello: un difficile bilanciamento. Processo penale e giustizia, Torino, p. 52, 2016.

CAPONE, Arturo. La motivazione della sentenza. In: GIULIANI, Livia; ORLANDI, Renzo (ed.). Indagini preliminari e giudizio di primo grado. Commento alla legge 23 giugno 2017, n. 103. Torino: Giappichelli, 2018, p. 297.

CAPONE. Arturo. Appello del pubblico ministero e rinnovazione istruttoria. In: BARGIS, Marta; BELLUTA, Hervé. La riforma delle impugnazioni tra carenze sistematiche e incertezze applicative (Commento alla legge 23 giugno 2017, n. 103 e al d.lgs. 6 febbraio 2018, n. 11), Torino: Giappichelli, 2018, p. 53.

CAPRARO, Laura. Novità per l'appello: concordato sui motivi e obbligo di rinnovazione istruttoria. In: SCALFATI, Adolfo (ed.). La riforma della giustizia penale. Commento alla legge 23 giugno 2017, n. 103, Torino: Giappichelli, 2017, p. 201.

CAPRIOLI, Francesco. item "Condanna" (diritto processuale penale), in Enciclopedia del diritto, Ann. II, tome I, Milano, 2008, p. 103.

CAPRIOLI, Francesco. L'accertamento della responsabilità penale "oltre ogni ragionevole dubbio”. Rivista italiana di diritto e procedura penale, Milano, p. 65, 2009.

CARLIZZI, Gaetano. Libero convincimento e ragionevole dubbio nel processo penale. San Lazzaro di Savena: Bonomo, 2018.

CATALANO, Elena Maria. Ragionevole dubbio e logica della decisione. Alle radici del giusnaturalismo processuale. Milano: Giuffrè, 2016.

CERESA-GASTALDO, Massimo. Nuovi (discutibili) profili dell'inammissibilità delle impugnazioni. In: BARGIS, Marta; BELLUTA, Hervé (ed.). La riforma delle impugnazioni tra carenze sistematiche e incertezze applicative (Commento alla legge 23 giugno 2017, n. 103 e al d.lgs. 6 febbraio 2018, n. 11). Torino: Giappichelli, 2018, p. 11. 
CHIAVARIO, Mario. Sub Art. 6. In: BARTOLE, Sergio; CONFORTI, Benedetto; RAIMONDI, Guido (ed.). Commentario alla Convenzione europea per la tutela dei diritti dell'uomo e delle libertà fondamentali. Padova: Cedam, 2001, p. 153.

CLARK, Sherman J. The Juror, the Citizen, and the Human Being: The Presumption of Innocence and the Burden of Judgment. Crim. Law and Philos., Dordrecht, p. 421, 2014. https://doi.org/10.1007/s11572-013-9246-5

CONTI, Carlotta. Al di là del ragionevole dubbio. In: SCALFATI, Adolfo (ed.). Novità su impugnazioni penali e regole di giudizio. Legge 20 febbraio 2006, n. 46, “legge Pecorella”. Milano: Ipsoa, 2006, p. 87.

COPPI, Franco. No all'appello del pm dopo la sentenza di assoluzione. Il giusto processo, Milano, p. 6, 2003.

CORDERO, Franco. Procedura penale, VIII ed., Milano: Giuffrè, 2006.

D'ALESSANDRO, Francesco. L'oltre ogni ragionevole dubbio nella valutazione del nesso causale e della colpa: passi avanti della più recente giurisprudenza di merito e di legittimità. Cassazione penale, Milano, p. 2406, 2006.

DALIA, Gaspare. Convincimento giudiziale e ragionevole dubbio. Milano: Wolters Kluwer, 2018.

DANIELE, Marcello. Una prima applicazione giurisprudenziale della regola dell'al di là di ogni ragionevole dubbio. Rivista di diritto processuale, Padova, p. 254, 2007.

DELLA MONICA, Giuseppe. Contributo allo studio della motivazione. Padova: Cedam, 2002.

DELLA MONICA, Giuseppe. Il principio del libero convincimento. In: CATALANO, Elena Maria; CURTOTTI NAPPI, Donatella; DELLA MONICA Giuseppe; LORUSSO Sergio; MONTAGNA, Mariangela; PROCACCINO, Angela, Prova penale e metodo scientifico. Torino: Utet, 2009, p. 211.

DIDONE, Antonio. La c.d. "Legge Pecorella" e i giudizi pendenti in cassazione: prime riflessioni. Cassazione penale, Milano, p. 391, 2006.

FANCHIOTTI, Vittorio. Il giudizio. In: LATTANZI, Giorgio; MONETTI Vito (ed.). La Corte penale internazionale. Organi - Competenza - Reati - Processo. Milano: Giuffrè, 2006, p. 1221.

FANCHIOTTI, Vittorio; MIRAGLIA, Michela; PIERINI Jean Paul, La Corte penale internazionale. Profili sostanziali e processuali. Torino: Giappichelli, 2014. 
FERRUA, Paolo. Giusto processo: l'attuazione si misura con le incertezze della giurisdizione. Diritto e giustizia, Milano, n. 26, p. 31, 2001.

FERRUA, Paolo. La colpevolezza oltre ogni ragionevole dubbio. In: FILIPPI, Leonardo (ed.). Il nuovo regime delle impugnazioni tra Corte costituzionale e Sezioni unite. Padova: Cedam, 2007, p. 144.

FERRUA, Paolo. Il giudizio penale: fatto e valore giuridico. In: FERRUA, Paolo; GRIFANTINI, Fabio M.; G. ILLUMINATI Giulio; ORLANDI, Renzo, La prova nel dibattimento penale, IV ed., Torino: Giappichelli, 2010, p. 381.

FESTA, Roberto. Induzione, probabilità e verisimilitudine. In: GIORELLO, Giulio (ed.). Introduzione alla filosofia della scienza, II ed., Milano: R.C.S., 1999, p. 285.

GAITO, Alfredo. Il procedimento probatorio (tra vischiosità della tradizione e prospettive europee). In: ID. (directed by) La prova penale, vol. I, Torino: Utet, 2008, p. 102.

GAROFOLI, Vincenzo. I nuovi standards valutativi e gli epiloghi decisori nel giudizio. In: GAITO Alfredo (ed.). La nuova disciplina delle impugnazioni dopo la “legge Pecorella". Torino: Utet, 2006, p. 77.

GUALTIERI, Piero. Diritto di difesa e prova scientifica. Diritto penale e processo, Milano, p. 494, 2011.

IACOVIELLO, Francesco Mauro. La motivazione della sentenza penale e il suo controllo in cassazione. Milano: Giuffrè, 1997.

IACOVIELLO, Francesco Mauro. Lo standard probatorio dell'al di là di ogni ragionevole dubbio e il suo controllo in cassazione. Cassazione Penale, Milano, p. $3874,2006$.

ILLUMINATI Giulio, Giudizio. In: CONSO Giovanni; GREVI, Vittorio; BARGIS, Marta, Compendio di procedura penale, IX ed., Padova: Cedam, 2018, p. 882.

JONAKAIT, Randolph N. The American Jury System. New Haven and London: Yale University Press, 2003.

KOSTORIS, Roberto E. item "Giudizio" (diritto processuale penale), in Enciclopedia giuridica Treccani, vol. XV, Roma, 1997, p. 9.

KOSTORIS, Roberto E. Le modifiche al codice di procedura penale in tema di appello e di ricorso per cassazione introdotte dalla cd. "legge Pecorella". Rivista diritto processuale, Padova, p. 642, 2006. 
LANGBEIN, John H. The Origins of Adversary Criminal Trial. Oxford and New York: Oxford University Press, 2003. https://doi.org/10.1093/ acprof:oso/9780199287239.001.0001

LAUDAN, Larry. Is Reasonable Doubt Reasonable?. Legal Theory, New York, n. 9, p. 295, 2003.

LAUDAN, Larry. Truth, Error, and Criminal Law. An Essay in Legal Epistemology. Cambridge: Cambridge University Press, 2006. https://doi.org/10.1017/ CBO9780511617515

LILLQUIST, Erik. Recasting Reasonable Doubt: Decision Theory and the Virtues of Variability. U.C. Davis Law Rev., Davis, p. 86, 2002. https://doi.org/10.2139/ ssrn.349820

LIPPKE, Richard L. The Prosecutor and the Presumption of Innocence. Crim. Law and Philos., Dordrecht, p. 337, 2014. https://doi.org/10.1007/s11572-013-9208-y

LORENZETTO, Elisa. Reformatio in peius in appello e processo equo (art. 6 Cedu): fisiologia e patologia secondo le Sezioni unite. Diritto penale contemporaneo (web), October 5, 2016.

LORUSSO, Sergio. La regola del "ragionevole dubbio" e la riforma delle impugnazioni. In: GAROFOLI, Vincenzo (ed.). La sentenza della corte costituzionale 6 febbraio 2007, n. 26: un energico richiamo al metodo della giurisdizione, Atti del Convegno, Trani, 2-3 febbraio 2007. Milano: Giuffrè, 2007, p. 95.

LORUSSO, Sergio. La prova scientifica. In: GAITO, Alfredo. (directed by). La prova penale, vol. I, Torino: Utet, 2008, p. 341.

LOZZI, Gilberto. Reformatio in peius del giudice di appello e cognitio facti ex actis della Corte di cassazione. Rivista italiana di diritto e procedura penale, Milano, p. 631, 2004.

LOZZI, Gilberto. Lezioni di procedura penale, XIV ed., Torino: Giappichelli, 2020.

MARANDOLA, Antonella. Prime riflessioni sul "nuovo" giudizio d'appello, Diritto penale contemporaneo, Milano, 2, p. 159, 2018.

MARCONI, Diego. Per la verità. Relativismo e filosofia. Torino: Einaudi, 2007.

MARZADURI, Enrico. Il mutamento delle scienze processualistiche. L'unità del sapere penalprocessualistico. In: V. Garofoli (ed.). L'unità del sapere giuridico tra diritto penale e processo, Atti del Convegno. Bari, 21-22 maggio 2004. Milano: Giuffrè, 2005, p. 88. 
MARZADURI, Enrico. Sub Art. 5 1. 20 febbraio 2006 n. 46. Legislazione penale, Torino, p. 88, 2007.

MENNA, Mariano. La motivazione del giudizio penale. Napoli: Jovene, 2000.

MINHAS, Azhar J. Proof Beyond any reasonable doubt: Shifting Sands of a Bedrock. Northern Illinois Univ. Law Rev., DeKalb, p. 46, 2003.

MONTAGNA, Mariangela. La rinnovazione obbligatoria della prova in appello: problematiche applicative. Processo penale e giustizia, Torino, p. 1150, 2018.

NAJDOWSKI Cynthia J.; STEVENSON, Margaret C. (ed.). Criminal juries in the 21st century. Contemporary issues, psychological science, and the law. New York: Oxford University Press, 2019. https://doi.org/10.1093/oso/9780190658113.001.0001

NEWMAN, Jon O. Beyond "Reasonable Doubt". New York Univ. Law Rev., New York, p. 984, 1993.

NOBILI, Massimo. Il principio del libero convincimento del giudice. Milano: Giuffrè, 1974.

PADOVANI, Tullio. Il doppio grado di giurisdizione: appello dell'imputato, appello del P.M., principio del contraddittorio. Cassazione penale, Milano, p. 4023, 2003.

PALIERO, Carlo Enrico. Il «ragionevole dubbio» diventa criterio. Guida al diritto, Milano, n. 10, p. 73, 2006.

PAPAGNO, Claudio. L'interpretazione del giudice penale tra regole probatorie e regole decisorie. Milano: Giuffrè, 2009.

PAULESU, Pier Paolo. item "Presunzione di non colpevolezza", in Digesto penale, vol. IX, Torino, 1995, p. 694.

PAULESU, Pier Paolo. La presunzione di non colpevolezza dell'imputato, II ed., Torino: Giappichelli, 2009.

PERCHINUNNO, Vincenzo. La fase del giudizio. In: PISANI, Mario; MOLARI, Alfredo; PERCHINUNNO, Vincenzo; CORSO, Piermaria; DOMINIONI, Oreste; GAITO, Alfredo; SPANGHER, Giorgio, Manuale di procedura penale, VIII ed., Bologna: Monduzzi, 2008, p. 508.

PIERGALLINI, Carlo. La regola dell'“oltre ragionevole dubbio” al banco di prova di un ordinamento di civil law. Rivista italiana di diritto e procedura penale, Milano, p. 593, 2007.

PISANI, Mario. Durata ragionevole del processo penale e appellabilità delle sentenze. Rivista di diritto processuale, Milano, p. 3, 2006. 
PISANI, Mario. Riflessioni sul tema del "ragionevole dubbio". Rivista italiana di diritto e procedura penale, Milano, p. 1253, 2007.

RAMADAN, Hisham M. Reconstructing Reasonableness in Criminal Law: Moderate Jury Instruction Proposal. Journal of legislation, Notre Dame, p. 233, 2003.

RAMADAN, Hisham M. The Challenge of Explaining “Reasonable Doubt”. Criminal Law Bulletin, Boston, p. 65, 2004.

ROBERTS Paul; ZUCKERMAN, Adrian. Criminal Evidence. II ed., Oxford and New York: Oxford University Press, 2010.

ROMBI, Natalia. Le Sezioni unite e le condanne cartolari nel giudizio abbreviato d'appello. Processo penale e giustizia, Torino, p. 806, 2017.

RUGGIERI, Francesca. Beyond any reasonable doubt: una matrice di common law. In: INCAMPO, Antonio; SCALFATI, Adolfo (ed.). Giudizio penale e ragionevole dubbio. Bari: Cacucci, 2017, p. 307.

SCHABAS, William A. The International Criminal Court. A Commentary on the Rome Statute, II ed., Oxford: Oxford University Press, 2016.

SHAPIRO, Barbara J. "Beyond Reasonable Doubt" and "Probable Cause". Historical Perspectives on the Anglo-American Law of Evidence. Berkeley: University of California Press, 1991.

SHEPPARD, Steve. The Metamorphoses of Reasonable Doubt: How Changes in the Burden of Proof Have Weakened the Presumption of Innocence. Notre Dame Law Rev., Notre Dame, p. 1166, 2003. https://doi.org/10.2139/ssrn.411101

SPANGHER, Giorgio. Sistema delle impugnazioni penali e durata ragionevole del processo. Corriere giuridico, Milano, 10, p. 1261, 2002.

SPANGHER, Giorgio. Il "nuovo" giudizio di appello. Diritto penale e processo, Milano, p. 1329, 2018.

STEIN, Alex. Foundations of Evidence Law. Oxford and New York: Oxford University Press, 2005. https://doi.org/10.1093/acprof:oso/9780198257363.001.0001

STELLA, Federico. Giustizia e modernità. La protezione dell'innocente e la tutela delle vittime, III ed., Milano: Giuffrè, 2003.

STELLA, Federico. Sul divieto per il pubblico ministero di proporre appello contro le sentenze di assoluzione. Cassazione penale, Milano, p. 756, 2004. 
STELLA, Federico; GALAVOTTI, Maria Carla. «L'oltre il ragionevole dubbio» come standard probatorio. Le infondate divagazioni dell'epistemologo Laudan. Rivista italiana di diritto e procedura penale, Milano, p. 883, 2005.

SURACI, Leonardo. La rinnovazione del dibattimento in caso di proscioglimento. In: SPANGHER, Giorgio (ed.), La riforma Orlando. Modifiche al Codice penale, Codice di procedura penale e Ordinamento penitenziario, Pisa: Pacini, 2017, p. 255.

TARUFFO, Michele. La prova dei fatti giuridici. Nozioni generali. Milano: Giuffrè, 1992.

TARUFFO, Michele. Fatto, prova e verità (alla luce del principio dell'oltre ogni ragionevole dubbio). Criminalia, Pisa, p. 310, 2009.

TESORIERO, Salvatore. Luci e ombre della rinnovazione dell'istruttoria dibattimentale in appello per il presunto innocente. Giustizia penale, Roma, III, c. 79, 2017.

TRANCHINA, Giovanni; DI CHIARA, Giuseppe, item “Appello" (diritto processuale penale), in Enciclopedia del diritto, Agg. III, Milano, 1999, p. 202.

TRIGGIANI, Nicola. Lo standard dimostrativo nella decisione di colpevolezza. In: INCAMPO, Antonio; SCALFATI, Adolfo (ed.). Giudizio penale e ragionevole dubbio. Bari: Cacucci, 2017, p. 327.

UBERTIS, Giulio. Fatto, prova e verità (alla luce del principio dell'oltre ogni ragionevole dubbio). Criminalia, Pisa, p. 327, 2009.

VAGIAS, Michail; FERENCZ, Janos. Burden and Standard of Proof in Defence Challenges to the Jurisdiction of the International Criminal Court. Leiden Journal of International Law, Leiden, n. 28 (1), p. 133, 2015. https://doi.org/10.1017/ s0922156514000570

VARRASO, Gianluca. Ragionevole dubbio e prova delle esimenti. In: INCAMPO Antonio; SCALFATI, Adolfo (ed.). Giudizio penale e ragionevole dubbio. Bari: Cacucci, 2017, p. 339.

VIDMAR, Neil. (ed.). World Jury Systems. Oxford and New York: Oxford University Press, 2000. https://doi.org/10.1093/acprof:oso/9780198298564.001.0001

WALDMAN, Theodore. Origins of the legal doctrine of reasonable doubt. Journal of the History of Ideas, New York, p. 299, 1959. https://doi.org/10.2307/2708111

WHITMAN, James Q. The origins of reasonable doubt. Theological roots of the criminal trial. New Haven: Yale University Press, 2008. 
WRIGHT, Richard W. Causation, Responsibility, Risk, Probability, Naked Statistics and Proof: Pruning the Bramble Bush by Clarifying the Concepts. Iowa Law Rev., Iowa city, p. 1002, 1988.

\section{Additional information and author's declarations (scientific integrity)}

Conflict of interest declaration: The author confirms that there are no conflicts of interest in conducting this research and writing this article.

Declaration of authorship: all and only researchers who comply the authorship requirements of this article are listed as authors; all coauthors are fully responsible for this work in its entirety.

Declaration of originality: The author assures that the text here published has not been previously published in any other resource and that future republication will only take place with the express indication of the reference of this original publication; he also attests that there is no third party plagiarism or self-plagiarism.

\section{Editorial process information}

(http://www.ibraspp.com.br/revista/index.php/RBDPP/about/editorialPolicies)

- Submission date: 12.05.2021

- Preliminary control and similarity verification: 13.05.2021

- Review 1: 05.06.2021

- Review 2: 07.06.2021

- Editorial decision 1: 07.06.2021

- Correction round return: 23.06.2021

- Final editorial decision: 24.06.2021
Editorial team responsible

- Editor-in-chief: 1 (VGV)

- Associated-editor: 1 (BC)

- Reviewers: 2 


\section{HOW TO CITE (ABNT BRAZIL):}

CALLARI, Francesco. The defendant's guilt beyond a reasonable doubt in the Italian criminal justice system. Revista Brasileira de Direito Processual Penal, Porto Alegre, vol. 7, n. 2, p. 1227-1260, mai./ago. 2021. https://doi.org/10.22197/rbdpp.v7i2.577 